\title{
Building Customer Loyalty through Service Quality and Customer Trust with Customer Satisfaction as an Intervening Variable (Empirical Study at PT. Bank Cimb Niaga Medan Pemuda)
}

\author{
Femmy Melany Primadany ${ }^{\text {, Amrin Fauzi }}{ }^{2}$, Paham Ginting ${ }^{2}$ \\ ${ }^{1}$ Postgraduate Students Department of Management, Faculty of Economics and Business at Universitas, \\ Sumatera Utara, Indonesia \\ ${ }^{2}$ Postgraduate Lecturer Department of Management, Faculty of Economics and Business at Universitas, \\ Sumatera Utara, Indonesia
}

Corresponding Author: Femmy Melany Primadany

\begin{abstract}
The purpose of this study was to determine customer loyalty through service quality and customer trust with customer satisfaction as an intervening variable, empirical study at PT. Bank Cimb Niaga Medan Pemuda. This type of research is associative research. The research sample was 99 customers of CIMB Niaga Pemuda Medan. The data analysis technique uses path analysis and is processed using SPSS software. The results of this study indicate that service quality, customer trust, and customer satisfaction positively and significantly effect customer loyalty.
\end{abstract}

Keywords: Customer Loyalty, Service Quality, Customer Trust, Customer Satisfaction

\section{INTRODUCTION}

The banking sector is one sector that has an important role in national development, banks also have a strategic role in various productive business activities and as agents of development, which in turn will encourage overall economic activity.

According to Tjiptono and Chandra (2012), quality is a dynamic condition that affects products, services, people, processes, and the environment that meet or exceed expectations. The definition of service quality is defined as an effort to fulfill the needs and desires of consumers and the accuracy of delivery in balancing consumer expectations. If the service received or perceived is as expected, then the service quality is perceived as good and satisfactory, if the service received exceeds consumer expectations, then the service quality is perceived to be very good and of high quality.

Good service is often judged by consumers directly from employees as people who serve or also referred to as service producers, therefore efforts are needed to improve the quality of the service system provided in order to fulfill desires and increase satisfaction. Satisfaction is the feeling of someone who is satisfied or vice versa after comparing the reality and expectations received from a product or service (Kotler, 2009). Meanwhile, according to Zeithaml et al. (2009), satisfaction is a response or consumer responses regarding the fulfillment of needs.

According to Kotler (2009), trust is a company's willingness to depend on business partners. Trust depends on a number of interpersonal and interorganizational factors, such as competence, integrity, honesty, and the kindness of the company. Oliver (1999), states that trust is often seen as having longterm characteristics. A very different thing 
from customer satisfaction which is defined as an instant response to consumption.

Customer satisfaction is determined by the quality of products and services desired by customers, so quality assurance is a top priority for banks. According to Kotler (2009), defines satisfaction as a person's feeling of pleasure or disappointment that comes from the comparison between his impression of the performance or results of a product and his expectations. Consumer satisfaction means that the performance of an item or service is at least equal to what is expected.

According to Ali (2008), customer loyalty is defined as people who buy, especially those who buy regularly and repeatedly. A customer is someone who continuously and repeatedly comes to the same place to satisfy his desire by having a product or getting a service and paying for the product or service. Meanwhile, according to Gremler and Brown in Ali (2008) that customer loyalty is a customer who not only repurchases an item or service but also has a positive commitment and attitude towards a service company, for example by recommending others to buy.

PT. Bank CIMB Niaga Tbk. or better known as CIMB Niaga is a bank that was established in 1955. CIMB Niaga is one of the leading private banks in Indonesia and is currently the fourth largest bank in Indonesia in terms of assets. In Indonesia, retail customer management is divided into two areas consisting of the Greater Jakarta Area and Outside Greater Jakarta Area, where for outside Greater Jakarta it is further divided into Sumatra, West Java, East Java, Central Java, and East Indonesia.

CIMB Niaga is committed to maintaining sustainable growth and being oriented to integrity, quality services, prudent bank management and sound financial performance management. However, in 2015-2018 the quality of CIMB Niaga's services was considered to be still not good enough from the customer's point of view.
Based on the data, it can be seen that from 2015 to 2018 the quality of CIMB Niaga's services was considered to be still not good enough when compared to similar competitor banks. This can be caused by various factors such as the bank's physical facilities, service performance, employee responsiveness, employee knowledge, or employee empathy when serving customers.

People are now more selective in choosing banking services to place their funds in order to avoid the risk of loss due to poor performance of a bank. In this case, the element of trust is a key factor for companies to win the competition. According to Akbar and Parvez (2009), high customer commitment to the company will ensure long-term business continuity. Therefore, in addition to service quality, CIMB Niaga focuses on building customer trust to maintain long-term business sustainability. For this research, the data used is data on the number of customers at CIMB Niaga Medan Pemuda branch in 2016.

With so many banking options available, customers will naturally have many choices and considerations in deciding which banking service or bank will give them satisfaction in achieving their expectations. Having satisfied customers is not enough, customers must be very satisfied because customer satisfaction leads to loyalty and for that a bank must develop new strategies to satisfy customers.

The purpose of this study was to determine customer loyalty through service quality and customer trust with customer satisfaction as an intervening variable.

\section{RESEARCH METHODS}

This type of research is associative and descriptive research. Pandiangan (2015), associative research is research conducted to determine the relationship between variables that are built based on theory. Descriptive research is a type of research that aims to make a systematic, factual and accurate description of the facts 
and characteristics of the population of a particular area (Pandiangan et al., 2021).

The population is the entire member or group that forms the object that is subject to investigation by the researcher (Sinulingga, 2011). In addition, the population describes the generalization area consisting of objects/subjects that have certain qualities and characteristics determined by the researcher to be studied and then draw conclusions. The population in this study were customers of Bank CIMB Niaga Medan Pemuda Branch, as many as 13,757 people. According Pandiangan et al. (2018) in Sugiyono, purposive sampling is the selection of samples based on certain characteristics that are considered to have relevance to the characteristics of the population that have been known previously. The research sample was 99 customers of CIMB Niaga Pemuda Medan.

Data collection methods are library research. Library research of reference sources is a form of research that uses library facilities by examining theoretical discussions from various books, articles, and scientific works related to writing (Pandiangan, 2018).

The data analysis technique uses path analysis and is processed using SPSS software. Path analysis is a technique for analyzing causal relationships that occur in multiple regression if the independent variable affects the dependent variable not only directly but also indirectly (Tobing et al., 2018).

\section{RESULT}

\section{Brief Company History}

CIMB Niaga was established on September 26, 1955 under the name Bank Niaga. In the early decades of its establishment, the main focus was on building core values and professionalism in banking. As a result, Bank Niaga is widely recognized as a trusted provider of quality products and services. In 1987, Bank Niaga distinguished itself from its competitors in the domestic market by being the first bank to offer its customers banking services through ATM machines in Indonesia. This achievement is widely recognized as Indonesia's entry into the world of modern banking. The Bank's leadership in the application of the latest technology was increasingly recognized in 1991 by being the first to provide its customers with online banking services.

Bank Niaga became a public company on the Jakarta Stock Exchange and the Surabaya Stock Exchange (now the Indonesia Stock Exchange/BEI) in 1989. The decision to become a public company is a milestone for the Bank by increasing wider access to funding. This step became a catalyst for the development of the Bank's network throughout the country.

The Government of the Republic of Indonesia has for some time been the majority shareholder of CIMB Niaga during the financial crisis in the late 1990s. In November 2002, Commerce Asset-Holding Berhad (CAHB), now widely known as CIMB Group Holdings Berhad (CIMB Group Holdings), acquired the majority stake in Bank Niaga from the Indonesian Bank Restructuring Agency (IBRA). In August 2007 all shareholdings changed hands to CIMB Group as part of an internal reorganization to consolidate the activities of all CIMB Group subsidiaries with a universal banking platform.

In a separate transaction, Khazanah which is the majority shareholder of CIMB Group Holdings acquired the majority ownership of LippoBank on September 30, 2005. All of these shares changed hands to CIMB Group on October 28, 2008 as part of the same internal reorganization.

As the owner of the controlling shares of Bank Niaga (through CIMB Group) and LippoBank, since 2007 Khazanah has viewed the merger as an effort that must be taken in order to comply with the Single Presence Policy (SPP) that has been set by Bank Indonesia. This merger is the first merger in Indonesia related to the SPP policy. In May 2008, the name of Bank Niaga changed to CIMB Niaga. The agreement on the proposed 
Merger of CIMB Niaga and LippoBank was signed in June 2008, followed by the Application for Approval of the Merger Plan from Bank Indonesia and the issuance of the Notice of Approval for the Merger by the Ministry of Law and Human Rights in October 2008. LippoBank officially merged into CIMB Niaga on November 1, 2008 (Legal Day 1 or LD1) followed by the introduction of the new logo to the public.

The merger of LippoBank into CIMB Niaga is a big leap forward in the Southeast Asian banking sector. CIMB Niaga now offers its customers comprehensive banking services in Indonesia by combining strengths in retail, SME and corporate banking as well as payment transaction services. This merger makes CIMB Niaga the 5th largest bank in terms of assets, funding, credit and branch network area. With its commitment to integrity, persistence to place the utmost importance on customers and a passion for excellence, CIMB Niaga will continue to use all its resources to create synergies from this merger. All of these are CIMB Niaga's core values and are obligations that must be fulfilled for a very promising future.

\section{Hypothesis Test}

Table 1. Structural Equation t Test Results 1

\begin{tabular}{|c|c|c|c|c|c|c|}
\hline \multicolumn{7}{|c|}{ Coefficients $^{\mathrm{a}}$} \\
\hline \multirow{2}{*}{\multicolumn{2}{|c|}{ Model }} & \multicolumn{2}{|c|}{ Unstandardized Coefficients } & \multirow{2}{*}{$\begin{array}{l}\text { Standardized Coefficients } \\
\text { Beta }\end{array}$} & \multirow[t]{2}{*}{$\mathbf{t}$} & \multirow[t]{2}{*}{ Sig. } \\
\hline & & $\mathbf{B}$ & Std. Error & & & \\
\hline \multirow[t]{3}{*}{1} & (Constant) & 7.363 & 2.206 & & 3.337 & .001 \\
\hline & Service Quality & .371 & .088 & .371 & 4.233 & .000 \\
\hline & Customer Trust & .457 & .124 & .324 & 3.690 & .000 \\
\hline
\end{tabular}

Table 2. Structural Equation t Test Results 2

\begin{tabular}{|c|c|c|c|c|c|c|}
\hline \multirow{2}{*}{\multicolumn{2}{|c|}{ Model }} & \multicolumn{2}{|c|}{ Unstandardized Coefficients } & \multirow{2}{*}{$\begin{array}{l}\text { Standardized Coefficients } \\
\text { Beta } \\
\end{array}$} & \multirow[t]{2}{*}{$\mathbf{T}$} & \multirow[t]{2}{*}{ Sig. } \\
\hline & & B & Std. Error & & & \\
\hline \multirow[t]{4}{*}{1} & (Constant) & .480 & 1.290 & & .372 & .711 \\
\hline & Service Quality & .112 & .053 & .164 & 2.115 & .037 \\
\hline & Customer Trust & .549 & .073 & .569 & 7.482 & .000 \\
\hline & Customer Satisfaction & .124 & .056 & .181 & 2.202 & .030 \\
\hline
\end{tabular}

The results of this study indicate that service quality, customer trust, and customer satisfaction positively and significantly effect customer loyalty.

\section{CONCLUSION AND SUGGESTION Conclusion}

The results of this study indicate that service quality, customer trust, and customer satisfaction positively and significantly effect customer loyalty.

\section{Suggestion}

Based on the results of the research and the conclusions above, some suggestions are given as follows:

1. In relation to service quality, customers still think that the response to customer requests is not fast and efficient enough. Therefore, if there are many queues due to services that are not fast enough, the company can install a queue machine with better quality and arrange the layout of the equipment and supplies needed to complete the work so as to create operating efficiency. For example, the placement of photocopiers that can be easily reached by Customer Service and Tellers so as to accelerate employee mobility in serving customers.

2. In terms of customer trust, the lowest rating is on customer confidence in the ability of employees to deliver services. The company can schedule regular monthly training and for new employees, training periods should be carried out for a certain period of time in order to adapt to the new environment. Employees should also be equipped with good communication skills so that 
customers feel comfortable and calm in transacting.

3. In terms of customer satisfaction, although on average it is included in the high category, the physical aspect is perceived as the lowest by customers in forming satisfaction. Therefore, CIMB Niaga management should pay attention to this matter to improve physical facilities such as: providing parking locations, providing comfortable waiting chairs, and placing internet banking machines in the automated teller machine (ATM) room.

4. In terms of customer loyalty, PT. Bank CIMB Niaga Pemuda Medan needs to

Acknowledgement: None

\section{Conflict of Interest: None}

\section{Source of Funding: None}

\section{REFERENCES}

1. Akbar M. M. \& Parvez. (2009). Impact of Service Quality, Trust, and Customer Satisfaction Loyalty. ABAC Journal, 29(1), 24-38.

2. Ali, Hasan. (2008), Marketing, Jakarta: PT. Buku Kita.

3. Kotler, Keller. (2009). Manajemen Pemasaran. Jakarta: PT. Indeks.

4. Oliver, R.L. (1999). Whence Customer Loyalty?. Journal of Marketing, 63, 3344.

5. Pandiangan, Saut Maruli Tua. (2015). Analisis Lama Mencari Kerja Bagi Tenaga Kerja Terdidik di Kota Medan. Skripsi. Medan: Fakultas Ekonomi dan Bisnis, Program Studi Ekonomi Pembangunan, Universitas Sumatera Utara.

https://www.academia.edu/52494724/A nalisis_Lama_Mencari_Kerja_Bagi_Ten aga_Kerja_Terdidik_di_Kota_Medan.

6. Pandiangan, Saut Maruli Tua. (2018). Analisis Faktor-faktor yang Mempengaruhi Penawaran Tenaga Kerja Lanjut Usia di Kota Medan. Tesis. Medan: Fakultas Ekonomi dan Bisnis, conduct an analysis to see what causes customers to be quite satisfied with the service but have not yet reached the stage of referring the company to other parties. Currently customers of PT. Bank CIMB Niaga is at the stage of using more than one product and still chooses to be a customer but has not yet reached the stage of recommending a bank and its services.

5. It is hoped that further research will select PT. Bank CIMB Niaga Pemuda Medan as the object of research should also consider other factors besides service quality, customer satisfaction and trust in relation to loyalty.

Program Studi Ilmu Ekonomi, Universitas Sumatera Utara. http://repositori.usu.ac.id/bitstream/hand le/123456789/10033/167018013.pdf?se quence $=1 \&$ isAllowed $=\mathrm{y}$.

7. Pandiangan, Saut Maruli Tua, Rujiman, Rahmanta, Tanjung, Indra I., Darus, Muhammad Dhio, \& Ismawan, Agus. (2018). An Analysis on the Factors which Influence Offering the Elderly as Workers in Medan. IOSR Journal of Humanities and Social Science (IOSRJHSS), 23(10), 76-79. DOI: 10.9790/0837-2310087679.

http://www.iosrjournals.org/iosrjhss/papers/Vol.\%2023\%20Issue10/Vers ion-8/K2310087679.pdf.

8. Pandiangan, Saut Maruli Tua, Resmawa, Ira Ningrum, Simanjuntak, Owen De Pinto, Sitompul, Pretty Naomi, \& Jefri, Riny. (2021). Effect of E-Satisfaction on Repurchase Intention in Shopee User Students. Budapest International Research and Critics Institute-Journal, 4(4), 7785-7791. DOI: https://doi.org/10.33258/birci.v4i4.2697.

9. Sinulingga, Sukaria. (2011). Metode Penelitian. Medan: USU Press.

10. Tjiptono, Fandy \& Chandra. (2012). Pemasaran Strategik. Yogyakarta: CV. Andi Offset.

11. Tobing, Murniati, Afifuddin, Sya'ad, Rahmanta, Huber, Sandra Rouli, Pandiangan, Saut Maruli Tua, \& Muda, 
Femmy Melany Primadany et.al. Building customer loyalty through service quality and customer trust with customer satisfaction as an intervening variable (empirical study at PT. Bank Cimb Niaga Medan Pemuda).

Iskandar. (2018). An Analysis on the Factors Which Influence the Earnings of Micro and Small Business: Case at Blacksmith Metal Industry. Academic Journal of Economic Studies, 5(1), 1723. https://www.ceeol.com/search/articledetail?id=754945.

12. Zeithaml, Valarie A., Mary Jo Bitner \& Dwayne D. Gremler. (2009). Services Marketing - Integrating Customer Focus Across The Firm 5.
How to cite this article: Primadany FM, Fauzi A, Ginting P. Building customer loyalty through service quality and customer trust with customer satisfaction as an intervening variable (empirical study at PT. Bank Cimb Niaga Medan Pemuda). International Journal of Research and Review. 2021; 8(11): 240-245. DOI: https:// doi.org/10.52403/ijrr.20211132 